Pegem Journal of Education \& Instruction, 3(2), 2013, 51-61

Pegem Eğitim ve Öğretim Dergisi, 3(2), 2013, 51-61

www.pegegog.net

ÖĞRETMENLERIN ILETIŞiM BECERISI VE EMPATiK EĞiLiM DAVRANIŞLARININ ÇOCUK SEVME DÜZEYLERI ÜZERINE ETKISI

\title{
COMMUNICATION SKILLS OF TEACHERS AND THE EFFECT OF EMPHATIC TENDENCY BEHAVIOR ON LEVELS OF LIKING OF CHILDREN
}

\author{
Celal Teyyar UĞURLU*
}

\author{
${ }^{a}$ Cumhuriyet Üniversitesi Eğitim Fakültesi, Sivas/Türkiye
}

\section{Özet}

$\mathrm{Bu}$ araştırmanın amacı ilköğretim okullarında öğretmenlerin iletişim becerileri ile empatik eğilimlerinin çocuk sevme düzeylerine etkisini incelemektir. Araştırma öğretmenlerin iletişim becerileri ve empatik eğilimlerinin çocuk sevme (öğrenciler) düzeylerini ne derece etkilediğini birlikte ve tek tek ortaya koymaya çalışmaktadır. Araştırmanın hedef evrenini 2011-2012 öğretim yılında Sivas il merkezinde 81 ilköğretim okulunda görev yapan 2076 öğretmen oluşturmaktadır. Illköğretim okullarından 35 okul random yöntemiyle belirlenmiştir. Bu okullarda görev yapan 906 öğretmen araştırmanın örneklemini oluşturmaktadır. Ölçekler 35 ilköğretim okulunda araştırmacı tarafından uygulanmıştır. Uygulanan ölçeklerden işlenmeye uygun 416 ölçek değerlendirmeye alınmıştır. Araştırma verileri, "iletişim Becerilerini Değerlendirme Ölçeği" , "Empatik Eğilim Ölçeği" ve "Barnett Çocuk Sevme Ölçeği" ile toplanmıştır. Araştırma sonucunda öğretmenlerin iletişim becerileri ile empatik eğilimlerinin çocuk sevme düzeylerini etkilediği, iletişim becerileri ile empatik eğilimlerin birlikte bu etkiyi biraz daha artırdığı görülmüştür.

Anahtar kelimeler: iletişim, empati, çocuk sevme.

\begin{abstract}
The purpose of this study was to investigate the communication skills of elementary school teachers and the effect of their emphatic tendencies on their levels of liking of children. This study tried to reveal the communication skills of the teachers and how their levels of liking of children affect their emphatic tendencies together and one by one. The population included 2076 teachers who worked at 81 elementary schools in Sivas province in the 2011-2012 academic years. Within the elementary schools, 35 schools were randomly selected. The sample of this study comprised 906 teachers who worked at these schools. Out of the applied scales, 416 actionable scales were evaluated. The data was collected via "Communication Skills Evaluation Scale", "Emphatic Tendency Scale" and "Barnett Liking of Children Scale". It was concluded from the study that the communication skills and emphatic tendencies of the teachers affected their levels of liking of children and communication skills together with the emphatic tendencies increased this effect a little more.
\end{abstract}

Keywords: Communication, empathy, liking of children.

*Yazar: celalteyyar@yahoo.com 


\section{Giriş}

Insanlar çevreleriyle sürekli etkileşim ve iletişim halindedir. İnsanlar arasında gerekli bilginin üretilip aktarılması için iletişime gereksinim vardır. Empati, iletişim kurmak zorunda olan insanoğlu için iletişimin niteliğini güçlendirebilir. İletişim, empatik tepkilerle güçlendirilirse mesajın karşıya iletilmesi ve anlamlandırılması daha kolay gerçekleşir (Arıcan, 2003; Dökmen, 2002; Şahin, 1998; Çetinkanat, 1996). Empati, iletişim esnasında gerçekleştirilir. Kendisini karşısındaki kişinin yerine koyarak düşünmeye çalışma, onu anlama, duygularını hissetme olarak tanımlanan empati iletişimin daha nitelikli gerçekleşmesine yardımcı olur. Empati bir iletişim becerisi olarak kabul edilebilir. iletişim becerisi olarak empatik davranışlar sergileyen bir insanın sosyal olarak birçok davranışının bundan etkileneceğini söylemek mümkündür. Bu nedenle iletişim becerisi ve empatik eğilimlerin çocuk sevme düzeyini açıklaması beklenebilir. Tutuk, Al ve Doğan'ın (2002) öğrenciler üzerinde yaptığı araştırmada ve Hacıoğlu'nun (2007) okul yöneticileri üzerinde yaptığı araştırma sonucunda iletişim becerileri ile empatik eğilim düzeyleri arasında pozitif yönlü bir ilişki bulunmuştur. Söz konusu araştırma sonuçları iletişim becerileri ile empatik eğilim düzeyleri arasındaki olumlu ilişkiyi ortaya koymaktadır.

Öğretmenlerin öğrencilerine karşı sergileyecekleri tutum ve davranışlar öğrencilerin öğretmenlerine karşı tutumlarını, davranışlarını ve ilgilerini farklılaştırabilecektir. Öğretmenlerin öğrencileri ile olan etkileşimlerinde kullanılan iletişim becerileri önemli bir yere sahiptir (Ergün ve Özdaş, 1999). BozkurtBulut'a göre (2003), etkili öğretmenlerin iletişim becerilerinin daha yüksek olduğu düşünülmektedir. Kendini verimli olarak algılayan öğretmenlerin iletişim becerilerinin de yüksek olacağı varsayılmaktadır. Iletişim becerilerinden birisi olarak empati, çocuk sevme davranışlarına olumlu olarak katkı sağlamaktadır. Illetişim sürecinde mesajı karşıya aktaran kişi olarak öğretmen iletişim sürecini empatik tepkileriyle güçlendirdiğinde karşı taraf üzerindeki etkisi artar.

Öğretmenlerin sahip olmaları gereken özelliklerden birisi olarak çocuk sevme (Ergün ve Özdaş, 1999) öğretmenler için önemlidir. Çocukları seven kişilerin öğretmenliğe daha yatkın oldukları belirtilir (Veenman, 1999). Çocuklara sevgi ile yaklaşılan ortamlarda disiplin sorunlarının da azalacağı ifade edilmektedir (Ergün ve Özdaş, 1999). Bu ilişkiler temelinde, Illetişim becerileri ve empatik eğilim düzeylerinin öğretmenlerin çocuk sevme davranışlarını artırması beklenir.

\section{Iletişim}

iletişime, bilgilerin, duyguların, becerilerin simgeler kullanılarak aktarılması, anlam arama çabası, olgu değiş tokuşu gibi anlamlar yüklemek mümkündür (Cüceloğlu, 2005, Dökmen, 2002) Dökmen (2002) iletişimi, katılanların, bilgi/sembol üreterek birbirlerine ilettikleri ve bu iletileri anlamaya yorumlamaya çalışıkları bir süreç olarak tanımlar.

Iletişim insan yaşamının sürdürülmesinde en temel araçlardan bir tanesidir. insan ancak ilişkileri içinde var olabilen bir varlıktır ( Cüceloğlu, 2005). Etkili iletişim becerileri, insan ilişkilerini ve her türlü meslek alanında ilişkileri kolaylaştıııcı özelliğe sahip olabilmektedir. Özellikle insanlarla daha çok bir arada olmayı gerektiren meslek alanlarında çalışanların iletişim becerilerine daha fazla hakim olmaları gerekmektedir (Korkut, 2005, 143). Toplumsal yaşam iletişim üzerine kuruludur. Bu nedenle etkili iletişime ve bunu sağlayan koşullara gereksinim vardır. Bu koşullardan bir tanesi de empatidir. Çünkü, iletişim aracılığıyla insan diğerlerini anlamak ve kendini anlatmak durumundadır (Doğuş, 2011). iki taraf arasında bilgi akışı sağlamanın yolu olarak iletişim, karşı tarafın özelliklerini, niteliklerini dikkate alarak bilginin anlamlı bir şekilde karşıya taşınmasıdır. Zıllığlu'na göre (1996) iletişim toplum yaşamı içinde kurulan paylaşılan ve geliştirilen anlamların mekanda taşınmasını zamanda korunmasını sağlar. iletişimde kaynak ile hedef arasında bir bağııık vardır. Bu karşılıklı bağımlılıkta fiziksel, etki-tepki, empati ve etkileşim gibi dört düzeyden söz edilir. Ancak iletişimde bu düzeylerin iletişim sürecinde bulunma ölçüsü farklılaşabilir $(s, 289)$. Iletişim ile ilişkili alan yazında bazı araştırmaları görmek mümkündür. Bunlar, duygusal iletişim ve tükenmişlik (Miller v.d., 1995), iletişim ve memnuniyet (Meeks, Hendrick ve Hendrick, 1998; Wanzer, Butterfield ve Gruber, 2004), empati ve iletişim (Tutuk, Al ve Doğan, 2002) 
formal ve informal iletişim ile memnuniyet (Aylor ve Oppliger, 2003) bireyler arası iletişim ve empatik duyarlıık (Töremen, Ekinci ve Karakuş, 2006) gibi araştırmalardır. Söz konusun araştırmalar iletişim becerilerinin insan ilişkileri sonucu oluşan farklı örgütsel değişkenlerle ilişkisini olduğunu ortaya koymaktadır. Bu değişkenlerden bir tanesi de empatidir.

\section{Empati}

Empati, karşıdaki kişinin duygularıı anlamaya odaklı bir yaklaşım içermektedir. Dökmen (2002) empati tanımını şu şekilde yapmaktadır; Empati, bir insanın, kendisini karşısındaki insanın yerine koyarak onun duygularını ve düşüncelerini doğru olarak anlamasıdır. Badea ve Pana'ya göre (2010) empati diğerlerinin duygularını anlamadır. Diğerlerinin duygularını yaşama değildir. Fakat biz diğerlerinin duygularını kendi deneyimlerimizden anlıyoruz. Özellikle sözsüz kanallarla diğerlerinin duygularını anlamak ve açıklamak amaçlanır. Goleman'a göre (1998) ise empati, bir kişinin, diğer bir kişinin perspektifinden olaylara bakması anlamına gelir (McAllister ve Irvine, 2002). Bu yanıla, empatinin iletişimi kolaylaştırdığı söylenebilir. Empati iletişim sürecini kolaylaştıran ve onu etkili kılan bir unsur olarak kabul edilebilir.

Bugün, empatinin öğretilebilir ve öğrenilebilir bir beceri olduğuna ilişkin bilgiler mevcuttur. Öncelikle empati bir karakter özelliği olarak düşünülmekte iken, artık empatinin öğretilebilecek ve öğrenilebilecek bir beceri olduğu kabul edilmektedir (Pala, 2008). iletişim sürecinde kendisi ile empati kurularak iletişim sağlanılan kişi, empati kurarak iletişim sürecini gerçekleştiren kişiyi zaman içerisinde model alabilir (Karcı, 2011). Empati ile ilişkili olarak yapılan çalışmalarda alan yazında yer alan çalışmalara rastlamak mümkündür. Bunlar: Okul kültürü ve empati (Barr, 2011) duygusal zeka ve empati becerileri (DumanKeskin, 2010) çatışma eğilimi ve empati (Barut, 2004) ahlaki yargı yetenekleri ve empati (Çiftçi, Arıdağ ve Yüksel, 2010) empatik eğilim ve eleştirel düşünme (Ekinci, 2009), empati öğretimi ve kültürel duyarlıık (Eva Lu, Dare ve Gellman, 2008) gibi çalışmalardır. Özellikle empati ile duyarılık, eleştirel düşünme, yargılama gibi kavramlar ilişkisinin ön plana çıktı̆ıını görmek mümkündür. Bir insana ya da nesneye karşı daha duyarlı davranış sergilemede empati önemli bir değişken olabilir mi? Empatik davranışların karşımızdaki bir kişiye olan sevgi ve ilgimizi artırabilir mi? sorularını düşünmek gerekir.

\section{Çocuk Sevme}

Fromm'a göre (1994) sevgi insanlarda bulunması gereken olumlu bir güç, öğrenilmesi ve uygulanması gereken bir sanattır. Gerçek sevgi; ilgi, sorumluluk, saygı ve bilmek ile sıkı sıkıya bağlıdır. Sevgi, kendini tanımış, olumlu kişilik yapıları geliştiren, bilgi, yaratıcılık, üretkenlik, açılarından belli bir olgunluğa erişmiş kimseler tarafından kendi bütünlüğünü ve bireyselliğini koruyarak gerçekleştirilen bir birlik olarak ifade edilir (Akt.Özmen, 1999). Sevgi, ilgi ve hoşgörü ile karşının hakkına saygı göstermek ve korumaktır. Kişinin kendisini aşması, doğaya, çevreye, tüm canlılara karşı duyarlı ve sorumlu olması demektir (Özmen, 1999). Öğretmenlik mesleği sevmeyi gerektiren bir meslek olarak iletişim, empatik ve çocuk sevgisi üzerine temellendirilebilir.

Öğretmenlerin sınıf içi iletişim becerilerinin niteliği öğrencilerin başarılarının belirleyicisi olabilmektedir (Ergin ve Birol, 2000). Öğretmenlerin öğretmenlik becerilerini etkili bir şekilde oynamalarında iletişim önemli bir yere sahiptir (Pehlivan, 2005). Gelbal ve Duyan'ın (2010) yaptıkları araştırma sonucunda, 40-50 yaş grubunda olan, evli olan, çocuk sahibi olan ve sınıf öğretmenliği yapan öğretmenlerin çocuk sevme puanları daha yüksek bulunmuştur. Öğretmenlerin iletişim becerileri, empatik eğilimleri ve çocuk sevme düzeyleri arasında bir ilişki olduğu varsayılmaktadır. Bu nedenle bu araştırmada bu üç değiş̧enin aralarındaki ilişki incelenmiştir.

\section{Iletişim Becerileri, Empatik Eğilim ve Çocuk Sevme Düzeyi Arasındaki ilişki}

Öğretmen sınıf içerisinde öğrenmeyi sağlayan ve bilgi aktaran konumunun yanında olumlu iletişim becerileri sunması gerektiğinin de bilincinde olmalıdır. Öğretmenin sahip olduğu iletişim becerileri 
öğretimin kalitesini de artırmaktadır (Karagöz ve Kösterelioğlu, 2008; Bolat, 1996). Etkili iletişim becerileri, örgütün etkililiğini artıran bir unsurudur. İletişim, yönetim süreçlerinden birisi olarak örgüt yönetiminde önemli bir yere sahiptir. İletişim sürecinde karşıdaki kişiye duyarlı olma, empatik davranabilme (Şişman, 2002) çift yönlü iletişimin doğası gereğidir. İletişim sürecinde, empatik eğilimler iletişimin daha sağıklı gerçekleşmesine neden olmaktadır.

Öğretmenlerin öğrencilere ilişkin sahip olmaları gereken özellikler vardır. Bu özelliklerden bir tanesi de çocuk sevgisidir (Gelbal ve Duyan, 2010). Iletişim sürecinde öğrencilerle yakın ilişki içerisinde bulunmak, empatik davranmak ve çocuklara karşı sevgi ve güven ortamı oluşturmak öğrencilerin okul başarısı için önemli olabilir. Karcı'nın (2011) Brems'den (1989) aktardığına göre, empati ile sosyal duyarlık ve topluma uyum arasında pozitif bir ilişki vardır. Alanyazında iletişim becerileri ve empatik eğilim ilişkilerine ilişkin çalışmalara (Dev, 2010; Ekinci, 2009; Hacıoğlu, 2007) rastlanmakla birlikte çocuk sevme ve iletişim becerisi, empatik eğilim ilişkili çalışmaların eksikliği görülmektedir. Downing, Ryndak ve Clark'a göre (2000) eğitimci olmak için, çocukları sevmek, sabırlı, ilgili, nazik ve esnek olma, sakin kalabilmek gibi özellikler gereklidir (akt. Gelbal ve Duyan, 2010; Erdem ve Duyan, 2011). Öğretmenlik çocuklarla bir arada olmayı gerektiren bir meslektir. Bu nedenle iletişim becerilerinin niteliği çocuklara karşı gösterilen tutum ve davranışları etkileyebilmektedir. Öğretmen ve çocuk arasındaki ilişkide karşılıklı bağımlılık, etkileşim ve empati iletişimin gücünü artırmaktadır.

İletişim becerilerinin niteliklerinden birisi olarak empati, iletişime etki ederek çocuk sevme düzeylerini etkilediği düşünülmektedir. Özellikle alan yazında iletişim ve empati ile çocuk sevme arasındaki ilişkiyi araştıran öğretmenler üzerinde araştırmaların kısıtlı olması bu çalışmanın alana katkı sağlamasına neden olacağı düşünülmektedir. Öğretmenlerin iletişim becerileri ve empatik eğilimleri çocuk sevme düzeylerini ne derece etkilemektedir. Araştırma ile iletişim becerisi ve empatik eğilimin çocuk sevme üzerindeki etkisini ortaya çıkarmak, öğretmenlerin çocuk eğitimindeki ayrıcalıklı rolünü ortaya koymak açısından önemlidir. Çünkü öğretmenlerin çocukların sosyal ve duygusal gelişim farklılıklarını anlayarak gerekli ilgi ve sevgiyi öğrencilerine göstermeleri beklenir. Şahin ve Alnıak'a göre (2008) öğretmenler çocuklarla etkileşimde bulunarak çocukların gelişimlerinin şekillenmesinde yardımcı olmaktadırlar. Duyan ve Gelbal'a göre de (2008) öğretmenlerin sahip olmaları gereken özelliklerinden birisi çocuğu sevmektir. Durmuşoğlu Salatlı ve Erbay (2013) çocuk sevmeyi öğretmenlik için bir ön koşul olarak kabul etmektedirler. Bu amaçla bu araştırmada iletişim becerileri ve empatik eğilimlerin çocuk sevme düzeyleri üzerine yordayıcı etkiye sahip olup olmadığı araştırılmıştır.

Bu araştırmada aşağıdaki soruya yanıt aranmıştır:

i. Öğretmenlerin iletişim becerileri ve empatik eğilimleri, çocuk sevme düzeylerini olumlu yönde yordamakta mıdır?

\section{Yöntem}

Bu bölümde araştırmanın modeli, çalışma grubu, veri toplama araçları ve verilerin analizi açıklanmıştır.

\section{Araştırmanın Modeli}

Araştırmanın modeli ilişkisel tarama modeline dayalı betimsel bir çalışmadır. Bu çalışmada öğretmenlerin iletişim becerileri, empatik eğilimleri ve çocuk sevme düzeyleri arasındaki ilişki belirlenmeye çalışılmıştır. Alan yazında Brems (1989) empatik eğilim ve sosyal duyarlık (akt.Karcı, 2011), iletişim ve empatik eğilim (Ekinci, 2009; Hacıoğlu, 2011) ilişkileri tespit edilmiştir. Bu ilişkilerden yola çıkılarak iletişim ve empati, iletişim ve çocuk sevme, empati ve çocuk sevme ilişkileri belirlenen hipotezle test edilmiştir. 


\section{Evren ve Örneklem}

Araştırmanın evrenini 2011-2012 öğretim yılında Sivas il merkezinde ki 81 ilköğretim okulunda görev yapan 2076 öğretmen oluşturmaktadır. İlköğretim okullarından 35 okul random yöntemiyle belirlenmiştir. Bu okullarda görev yapan 906 öğretmen araştırmanın örneklemini oluşturmaktadır. Ölçekler 35 ilköğretim okulunda araştırmacı tarafından uygulanmıştır. Uygulanan ölçeklerden işlenmeye uygun 416 ölçek değerlendirmeye alınmıştır. Üzerinde çalışılan 416 ölçek, 0.05 anlamlılık düzeyinde ve 0.05 örnekleme hatası (Yazıcıoğlu ve Erdoğan, 2004) ile evreni temsil etmektedir. Örneklemi ifade eden sayısal bilgilere Tablo 1'de yer verilmiştir.

Tablo 1.

Örnekleme ilişkin Sayısal Veriler.

\begin{tabular}{llcc}
\hline & & Frekans & Yüzde (\%) \\
\hline Cinsiyet & Kadın & 200 & 48,8 \\
& Erkek & 216 & 51,2 \\
Branş & Okul Öncesi & 40 & 9,6 \\
& Sınıf Öğretmeni & 215 & 51,7 \\
\multirow{3}{*}{ Kıdem } & Diğer Alanlar & 161 & 38,7 \\
& $1-15$ yıl & 115 & 27,6 \\
\multirow{3}{*}{ Medeni Durum } & 6-10 yıl & 134 & 32,2 \\
& 11 yıl ve üstü & 167 & 40,2 \\
& Evli & 341 & 82,0 \\
& Bekar & 75 & 18,0 \\
\hline
\end{tabular}

Tablo 1'de görüldüğü gibi, örneklemde yer alan öğretmenlerin 203'ü (\%48,8) kadın, 216'sı (\%51,2) erkektir. Branş değişkeni açısından, 38'i $(\% 9,1)$ okul öncesi öğretmeni, 192'si (\% 46,2) sınıf öğretmeni, 137'si (\% 44,7) diğer alan öğretmenleridir. Kıdem değişkeni açısından 1-5 yıl 115 (\%27,6), 6-10 yıl 134 (\%32,2), 11 yıl ve üstü himet yılına sahip öğretmenlerden oluşmaktadır. Katılımcıların 236'sı $(\% 85,6)$ evli, 60 'ı $(\% 14,4)$ bekar öğretmendir.

\section{Veri Toplama Araçları}

Araştırmanın verileri, "Kişisel Bilgi Formu”, "Iletişim Becerilerini Değerlendirme Ölçeği” , "Empatik Eğilim Ölçeği" ve "Barnett Çocuk Sevme Ölçeği" ile toplanmıştır.

Kişisel Bilgi Formu: Öğretmenleringörüşleri, cinsiyet, medeni durum, görev süresi ve insan ilişkilerinde zorluk yaşadığınızı düşünüyor musunuz? değişkenlerine göre toplanmıştır.

Iletişim Becerilerini Değerlendirme Ölçeği (IBDÖ): İletişim becerilerini değerlendirme ölçeği Korkut (1996) tarafından geliştirilmiştir. Ölçek 5'li likert tipi bir ölçektir. Ölçekte toplam 25 madde yer almaktadır. Ölçekten alınabilecek en yüksek puan 125 en düşük puan ise 25 tir.Ölçeğin test-tekrar-test yöntemi ile yapılan güvenirlik çalışması sonucunda güvenirlik katsayısı .76 olarak, iç turarlılık katsayısı olarak Alfa değeri ise .80 olarak bulunmuştur. Bu çalışmada iletişim becerileri değerlendirme ölçeğinin iç tutarlılık katsayısı (Cronbach alfa) .90 olarak hesaplanmıştır.

Empatik Eğilim Ölçeği (EEÖ): Bireylerin kendilerine yönelik duygusal duyarlılığını ölçmeye yönelik ölçek Dökmen (1988) tarafından geliştirilmiştir. Empatik eğilim ölçeği ile ilgili 20 madde 5'li likert tipi sistem ile puanlanmıştır. Olumlu empati cümleleri 1-5 arasında puanlanırken, olumsuz empati cümleleri için ters kodlama yapılmıştır. Dökmen (1988) tarafından geçerlik ve güvenirliği yapılan çalışmada, güvenirlik katsayısı .91 olarak hesaplanmıştır.Bu çalışmada empatik eğilim ölçeği iç tutarlılık katsayısı (Cronbach alfa) .80 olarak hesaplanmıştır. Ölçekten alınabilecek en yüksek puan 100 en düşük puan ise 20'tir. Ölçeğin test tekrar test güvenirliği .82 olarak bulunmuştur. Ölçeğin Cronbach Alpha ile hesaplanan 
güvenirlik katsayısı .72 olarak bulunmuştur. Ölçekten alınacak puanların yüksekliği, öğretmenlerin empati becerilerinin olumlu yönde olduğunu göstermektedir.

Barnett Çocuk Sevme Ölçeği(BÇSÖ): Barnett Çocuk Sevme Ölçeği, Barnett ve Sinisi (1990) tarafından insanların çocuklara yönelik tutumlarını ölçmek amacıyla geliştirilmiştir. Duyan ve Gelbal (2008) tarafından Türkçe'ye uyarlaması yapılmışır. Ölçekte çocukları sevme durumlarını belirlemeye yönelik on dört madde bulunmaktadır. Barnett Çocuk Sevme .92 düzeyinde iç turarlıı̆̆a sahiptir. Test tekrar test güvenirlik katsayısı .85 olarak hesaplanmıştır. Maddeler "Hiç katılmıyorum" yanıtından, "Tamamen katılıyorum" yanıtına kadar yedi derecede görüş bildirmeleri istenilmiştir. Maddelerin dördü olumsuz, on madde ise olumlu anlam taşımaktadır. Ölçekten alınabilecek en yüksek puan 98 en düşük puan ise $14^{\prime}$ tür. Ölçekten alınan yüksek puanlar çocuklara karşı daha yüksek sevgi düzeyinin göstergesi olarak kabul edilmiştir. Bu çalışmada Cronbach Alpha ile hesaplanan güvenirlik katsayısı .91 olarak bulunmuştur. Ölçeklere ilişkin bilgiler Tablo 2'de verilmiştir.

Tablo 2.

Ölçeklere iliş̧kin istatistikler

\begin{tabular}{lllcccc}
\hline Ölçekler & $\mathbf{n}$ & $\mathbf{K}$ & $\begin{array}{c}\text { En düşük } \\
\text { puan }\end{array}$ & $\begin{array}{c}\text { En yüksek } \\
\text { puan }\end{array}$ & $\bar{x}$ & Ss \\
\hline IBDÖ & 416 & 25 & 72 & 125 & 104,96 & 9,89 \\
EEÖ & 416 & 20 & 47 & 100 & 72,16 & 7,89 \\
ÇSÖ & 416 & 14 & 32 & 70 & 56,60 & 5,46 \\
\hline
\end{tabular}

\section{Verilerin Analizi}

Araştırma verilerinin analizinde SPSS17 programı kullanılmışır. Ölçeklere ilişkin aritmetik ortalamalar, standart sapmalar, en yüksek ve en düşük puanlar hesaplanmıştır. Araştırmanın bağımlı değişkeni çocuk sevme düzeyi, bă̆ımsı değiş̧enleri ise iletişim becerileri ve empatik eğilimdir. Araştırmada çoklu regrasyon analiz tekniği olan aşamalı regrasyon kullanılmıştır.

Çoklu regrasyon bir bağımlı ve birden fazla bağımsız değişken arasındaki ilişkinin doğrusal bir yapı gösterdiği doğrusal regrasyon çözümlemesidir.

$\mathrm{Y}=\mathrm{a}+\mathrm{b}_{1} \mathrm{x}_{1}+\mathrm{b}_{2} \mathrm{x}_{2}$

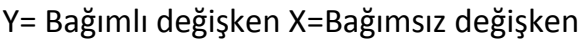

a: $X=0$ iken $Y^{\prime}$ nin alacağı değer (sabit)

b: X'deki 1 birim değişmenin Y'de yol açtığı ortalama değişim miktarı (regresyon katsayısı)

Aşamalı regrasyon yordanan değişkenle en yüksek düzeyde korelasyon gösteren yordayıcı değişkenlerin modele eklenmesi, en düşük düzeyde korelasyon gösterenlerin ise modelden çıkarılması esasına dayalı bir yöntemdir. Bu yolla yalnızca yordamaya katkısı anlamlı olan yordayıcı değişkenler kullanılarak regresyon eşitliği meydana getirilir (Kalaycı, 2010).

Verilerle regrasyon işlemlerinin yapılabilmesi için öncelikle normallik varsayımının sağlanıp sağlanmadığına bakılmıştır. Bu amaçla çarpıklık ve basıklık katsayılarına bakıımış ve normalliğin sağlandığı görülmüştür. İletişim becerileri, empatik eğilim ve çocuk sevme düzeylerine ilişkin çarpıklık (Skewness) ve basıklık (Kurtosis) değerlerinin -1 ile +1 arasında değerler aldığı görülmüştür. iletişim beceri çarpıklık değeri -.330 ve basıklık değeri .046; empatik eğilim çarpıklık değeri -.030 (Skewness) ve basıklık değeri -.091 (Kurtosis); çocuk sevme çarpıklık değeri -.1210 (Skewness) düzeyi basıklık değeri .964 olarak hesaplanmıştır.

Çoklu doğrusal regrasyon modelinin varsayımlarından biri de "otokorelasyon olmaması" varsayımıdır. Bu nedenle modeldeki Dubrin Watson katsayısı ile otokorelasyon olup olmadığı incelenmiştir. Dubrin Watson katsayıının 1,5 ile 2,5 civarındaki test değeri otokorelasyon olmadığını göstermektedir. Yordayıcı değişkenler arasında çoklu bağlantının olmaması varsayımının sınanması için 
değişkenler arasındaki ikili korelasyonlar incelenmiştir. ikili korelasyonlar incelendiğinde yordayıcı değişenler arasındaki en yüksek korelasyonun iletişim ve empati arasında .476 düzeyindedir. Ayrıca iletişim ve çocuk sevme .277; empati ve çocuk sevme arasında da .317 düzeyinde korelasyon vardır. Değişkenler arasında yüksek bir ilişki görülmemekle birlikte çoklu bağlantı olmadığından emin olmak için Tolerans, VIF ve $\mathrm{Cl}$ değerlerine de bakılmıştır. Regresyon modeli sonucunda oluşan modele ait Tolerance ve VIF değerleri bağımsız değişkenler arasında bir çoklu bağlantıya işaret (Tolerans değeri=.773 VIF değeri=1.294) etmemektedir. (Tolerance değeri tümünde $.20^{\prime}$ den büyük ve VIF değerleri $10^{\prime}$ dan düşüktür). "Collinearity Diagnostics" tablosunda ise 30'dan büyük Cl (Condition Index Değerleri=18.394 ve 27.684) değeri olmadığından çoklu bağlantı söz konusu değildir (Kalaycı, 2010).

\section{Bulgular}

\section{Araştırma Sorusuna iliş̧kin Bulgular}

Araştırmanın sorusu "Öğretmenlerin iletişim becerileri ve empatik eğilimleri, çocuk sevme düzeylerini olumlu yönde yordamaktadır" şeklinde düzenlenmiştir. Bu başlık altında öğretmenlerin iletişim becerilerinin çocuk sevme düzeylerini yordama durumunu ortaya koymak için çoklu regrasyon analizi stepwise metodu ile yapılarak sonuçlarına Tablo 3 'de yer verilmiştir.

Tablo 3.

Öğretmen Iletişim Becerileri Ve Empatik Eğilimlerinin Çocuk Sevme Düzeylerini Yordamasına ilişkin Aşamalı (Stepwise) Regrasyon Analizi Önkoşul Sonuçları.

\begin{tabular}{|c|c|c|c|c|c|c|c|c|c|c|}
\hline \multirow[t]{2}{*}{ Model } & \multirow[t]{2}{*}{$\mathbf{R}$} & \multirow[t]{2}{*}{$\mathbf{R}^{2}$} & \multirow{2}{*}{$\begin{array}{l}\text { Adj } \\
R^{2}\end{array}$} & \multirow{2}{*}{$\begin{array}{l}\text { Std. } \\
\text { Error } \\
\text { Of Est. }\end{array}$} & \multicolumn{5}{|c|}{ Change Statistics } & \multirow{2}{*}{$\begin{array}{l}\text { Dubrin- } \\
\text { Watson }\end{array}$} \\
\hline & & & & & $\begin{array}{l}\mathrm{R}^{2} \\
\text { Change }\end{array}$ & $\begin{array}{l}\mathrm{F} \\
\text { Change }\end{array}$ & df1 & df2 & $\begin{array}{l}\text { Sig. } F \\
\text { Change }\end{array}$ & \\
\hline 1 & .323 & .104 & .102 & 12.06 & .104 & 48.184 & 1 & 414 & .000 & 1.706 \\
\hline 2 & $.346^{\mathrm{b}}$ & .120 & .115 & 11.97 & .015 & 7.243 & 1 & 412 & .000 & \\
\hline
\end{tabular}

Modeldeki Dubrin Watson katsayısı otokorelasyon olup olmadığını göstermektedir. Genelikle 1,5 ile 2,5 civarında D.W. testi değeri otokorelasyon olmadığını göstermektedir. Birinci modelde sadece empati ile başlanmıştır. Sonuca göre empati tek başına çocuk sevmenin \% $10^{\prime}$ unu açıklamaktadır. İkinci modelde iletişim de eklenmektedir. Iletişim \% 015 ekleme yaparak açıklamayı yaklaşık \% 12'ye çıkarmıştır. Elbette iletişimin \% 015 etkisi empati ile olan ortak varyansı çıkarıldıktan sonra olandır.

Her iki değişkenin her birinin çocuk sevme ile ilişkisine ilişkin model 0.001 seviyesinde anlamlı bulunmuştur (Sig F Change). Dolayısıyla her iki değişkeninde çocuk sevme üzerinde rol oynadığı görülmektedir. Bağımsız değişkenlerin önem sırasının tespiti ßeta katsayısı değerleri hesaplanmıştır. Tablo 4'de bu katsayılar gösterilmektedir.

Tablo 4.

Öğretmen Iletişim Becerileri ve Empatik Eğilimlerinin Çocuk Sevme Düzeylerini Yordamasına ilişsin Aşamalı (Stepwise) Regrasyon Analizi Sonuçları.

\begin{tabular}{llllllll}
\hline \multicolumn{1}{l}{ Yordanan Değişken: Çocuk Sevme Düzeyi } & & & \multicolumn{3}{c}{ Korelasyon } \\
\hline Model & $\mathrm{B}$ & $\mathrm{ShB}$ & $\beta$ & $\mathrm{T}$ & $\mathrm{P}$ & İkili & Kısmi \\
1-Sabit & 45.626 & 4.609 & & 9.900 & .000 & & .323 \\
Öğretmen empatik eğilim & .434 & .062 & .323 & 6.941 & .000 & .323 & .323 \\
2- Sabit & 32.269 & 6.750 & & & & & .234 \\
Öğretmen empatik eğilim & .344 & .070 & .256 & 4.897 & .000 & .323 \\
Öğretmen iletişim becerisi & .185 & .069 & .141 & 2.691 & .007 & .262 & .131 \\
\hline
\end{tabular}


$Y=a+b X$

$Y=a+b^{1} x^{1}+b^{2} x^{2}$

Çocuk Sevme $=45.626+(.434)$. Empati

Çocuk Sevme $=32.269+(.344)$. Empati $+(.185)$.iletişim

Model 2'de Beta değeri en yüksek olan empatik eğilimdir $(\beta=0,256)$. Daha sonra ise iletişim $(\beta=0,141)$ değişkeni gelmektedir. Tek tek iletişim becerisi ve empatik eğilimlerin çocuk sevme üzerine ilişkisine bakıldığında empati ilişkisinin $r=.323$, iletişim becerisinin $r=.262$ korelasyon değeri ile düşük olduğu görülmektedir. Ancak her bir değişkenin etkisi kontrol edilerek yapılan analizde ise empatik eğilim $r=$ .234 iletişim becerisi $r=.131$ düzeyinde ilişkili olduğu görülmektedir.

\section{Tartışma ve Sonuç}

Bu çalışmada, öğretmenlerin iletişim becerileri ile empatik eğilimlerinin çocuk sevme düzeyleri ile ilişkisi incelenmiştir. Araştırma sonuçları, öğretmenlerin iletişim becerileri ile empatik eğilimlerinin çocuk sevme düzeylerini yordadığını göstermektedir. Araştırma sonuçları empatik eğilimin tek başına çocuk sevme düzeylerini $\left(R^{2}=.102\right) \% 10$ açıklarken, iletişim becerileri ile birlikte artırarak $\left(R^{2}=.115\right)$ yaklaşık \% 12 'sini açıklamaktadır. Iletişim becerileri ile empatik eğilimlerin çocuk sevme düzeylerini açıklama oranları tek tek ele alındığında düşük ve anlamlı bir düzeyde $(p=.000)$ açıkladığı görülmektedir. Bu sonuçlar, özellikle empatik eğilimin çocuk sevme düzeylerini daha çok açıkladığını göstermektedir.

Alanyazın incelendiğinde iletişim becerilerinin ve empatik eğilimlerin çocuk sevme düzeyleri ilişkisini yordayan araştırma sonuçlarına ulaşılamamıştır. Ancak alan yazında öğretmenlerin iletişim becerileri ve empatik eğilimlerinin düzeylerine ilişkin sonuçların yüksek olduğu bulgularına ulaşılmıştır. Iletişim becerisi ile okul başarısı arasında olumlu bir ilişkinin olduğu (Engin ve Birol, 2010) evli ve çocuk sahibi sınıf öğretmenlerinin çocuk sevme puanlarının yüksek olduğu (Gelbal ve Duyan, 2010) empati ile sosyal duyarlıık arasında ilişkinin bulunduğu (KarCı, 2011) farklı araştırma sonuçlarıyla belirlenmiştir. Arifoğlu ve Razı (2011) tarafından öğrenciler üzerinde yapılan araştırmada, iletişimle ilgili bilgi alan öğrencilerin empatik eğilim ölçeği puan ortalaması bilgi almayanlara göre daha yüksek bulunmuştur. Bu çalışmada da iletişim ve empatik eğilime ilişkin yeterliklerin çocuk sevme davranışlarını etkilediği görülmüştür.

Dökmen'e göre (1987) empati, sosyal uyuma katkısı olan temel insan özelliklerinden birisidir. Kişinin kendisiyle olan iletişimi, çevresiyle olan iletişiminin bir parçasıdır. Empati becerisi günlük yaşamın her anında kişiler arası ilişkileri kolaylaştıran çok önemli bir beceri olarak kabul edilir (Akt. Dinçyürek, 2004). İnsanlar kendileri ile empati kurulduğunda, anlaşıldıkları ve önem verildikleri duygusunu yaşarlar. Öğretmenlerin iletişim becerileri ve empatik eğilimleri de diğerleri ile olan ilişkilerinin niteliğini etkileyen önemli bir etkendir. Birey olarak çocuklara yönelik tepkilerin kaynağında iletişim becerisi ve empatik eğilimlerin doğasına ilişkin tutumlar ve davranışlar inkar edilemez. Dinçyürek'e göre (2004) öğretmen öğrencisiyle, doktor hastasıyla, anne-baba çocuklarıyla kurdukları empatik iletişim kişilerin karşısındakilerle daha fazla psikolojik paylaşımın yaşanmasını sağlayacaktır. Söz konusu durum öğretmenlerin iletişim becerisi ve empatik eğilimleri ile çocuk sevme düzeyleri ilişkisinde de görülebilir.

Alanyazında iletişim becerileri ve empatik eğilimlerin çocuk sevme düzeyi arasındaki ilişkiyi betimleyen araştırma sonuçlarının kıstıılığından dolayı bu çalışma alanyazına bir katkı sunmaktadır. Özellikle öğretmenlerin öğretmenlik meslek bilgisi dersleri içerisinde iletişim ve empati yeterliklerine ilişkin eğitim almaları onların öğrenci davranışlarının yönlendiricisi olmaları nedeniyledir. Öğretmenlerin, öğrencilerle ilişkilerinde öğrencileri dinleyen onlarla çift yönlü iletişimler kurabilen öğretmen olmaları beklenmektedir. Empatik eğilim, öğretmenlerin öğrencileri ile olan ilişkilerinde, iletişimlerinde onları anlamayı, kendisini karşısındaki insanın yerine koyarak onun duygularını ve düşüncelerini anlamayı gerektirmektedir. Öğretmenlerin sahip olmaları gereken iletişim becerisi ve empatik eğilimlerin çocukları sevme davranışlarına etki edebileceği beklenebilir. Bu nedenle bu araştırmada da iletişim becerisi ile empatik eğilim bağımsız değişken olarak alınarak çocuk sevme düzeylerine etkisi incelenmiştir. Sonuç 
olarak düşük düzeyde anlamlı bir ilişki bulunmuştur. Bu sonuç öğretmenlerin iletişim becerileri ile empatik eğilim düzeylerinin çocuk sevme düzeylerini etkilediğini ancak ilişkinin düşük olduğunu ortaya koymaktadır. Çocuk sevme düzeyleri iletişim becerileri ile empatik eğilim düzeylerinin dışında başka değişkenler tarafından da yordanmaktadır. Empatik eğilimin çocuk sevme düzeylerini daha fazla yordamasından hareketle, öğretmenlere verilecek "empatik eğitim" onların çocuk sevme tutum ve davranışlarını etkileyebilecektir. Yüksel'in (2004) yaptığı araştırmada da empati eğitiminin empati becerilerini geliştirdiği yönünde sonuçlara ulaşılmıştır. Kolayiş ve Yiğiter'e göre (2010) empati becerisi gelişmiş insanlar, başkaları tarafından sevilir ve kabul edilerek onaylanırlar. Bu sonuçlara göre, öğretmenlerin iletişim becerileri eğitimi ve empatik eğilim eğitimi almaları onların çocuk sevme düzeylerini etkileyebilecektir. Karahan, Sardoğan, Güven, Özkamalı ve Dicle (2006) yapmış oldukları araştırmada insan ilişkileri ve iletişim dersinin empatik beceri düzeyleri ile ilişkili olduğunu ortaya koymuşlardır. Bu nedenle, iletişim becerileri ve empatik eğilim düzeylerinin niteliğinin artırılması da öğretmenlerin çocuk sevme düzeylerine olumlu katkı sağlayabilir. Bu araştırma sonucunda iletişim becerileri ve empatik eğilim düzeylerinin öğretmenlerin çocuk sevme düzeylerinin düşük düzeyde yordayıcısı olması, öğretmenlerin iletişim becerileri ve empatik eğilim davranışlarının geliştirilmesi konusunda yetiştirilmelerini gerekli kılmaktadır. Öğretmenlerin okul içinde ve okul dışında sergileyecekleri davranışlar iletişim becerileri ve empatik eğilim düzeylerini yansıtmaktadır. Bu davranışların çıktısı olarak çocuk sevme öğretmen davranışlarının önemli bir yanını oluşturmaktadır. Bu nedenle öğretmenler iletişim becerilerini geliştirici drama kursları ile eğitilmeleri önerilebilir. Ayrıca empatik ilişkilerin uygulama örneklerini öğretmenlerle paylaşılacak eğitici çalışmalara yer verilmelidir. Öğretmenlerin çocuk kitapları okumaları, çocuk dergilerini takip etmeleri de öğretmenlerin çocuk sevme davranışlarını etkileyebilecektir. Çünkü çocukların dünyasını tanımak onlara karşı daha empatik tepkiler üretilmesine neden olacaktır.

\section{Kaynakça}

Arifoğlu, B. ve Razı, G.S. (2011). Birinci sınıf hemşirelik öğrencilerinin empati ve iletişim becerileriyle iletişim yönetimi dersi akademik başarı puanı arasındaki ilişki. DEUHYO ED, 4 (1), 7-11.

Aylor, B. ve Oppliger, P. (2003). Communication education, 52 (2), 122-134.

Badea, L. ve Pana, N.A. (2010). The role of empathy in developing the leader's emotional intelligence. Theoretical and Applied Economics, 17 (543), 69-78.

Barr, J. J. (2011). The relationship between teachers' empathy and perceptions of school culture. Educational Studies, 37 (3), 365-369.

Barut, Y. (2004). Öğretmenlerin empatik eğilim düzeyleri ile çatışma eğilimi düzeylerinin değişkenler açısından incelenmesi. 13. Ulusal Eğitim Bilimleri Kurultayı, İnönü Üniversitesi, Malatya.

Bozkurt-Bulut, N. (2003). ilköğretim sınıf öğretmenlerinin iletişim becerilerine ilişkin algılarının çeşitli değişkenler açısından incelenmesi, XII. Eğitim Bilimleri Kongresi, 15-18 Ekim, Gazi Üniversitesi: Antalya.

Çiftçi Arıdağ, N. ve Yüksel, A. (2010). Üniversite öğrencilerinin ahlaki yargı yetenekleri ile empati becerileri arasmdaki ilişkinin incelenmesi. Kuram ve Uygulamada Eğitim Bilimleri, 10 (2), 683-727.

Cüceloğlu, D. (2005). Yeniden insan insana, İstanbul: Remzi.

Dev, N. (2010) ilköğretim okullarında görev yapan yönetici ve öğretmenlerin empatik beceriler açısından karşılaştırılması. Yayımlanmamış Yüksek Lisans Tezi, Yeditepe Üniversitesi, İstanbul.

Dinçyürek, S. (2004). Üniversite öğrencilerinin empatik becerilerinin çeşitli değişkenler açısından incelenmesi. Marmara Coğrafya Dergisi, 10, 95-116.

Doğuş, Y. (2011) Okul yöneticileri ve öğretmenlerin bakışı ile empatik iletişim. e-Journal of New World Sciences Academy, 6 (1), 696-707. 
Dökmen, Ü. (1988). Empatinin yeni bir modele dayanılarak ölçülmesi ve psikodrama ile geliştirilmesi. Ankara Üniversitesi Eğitim Bilimleri Fakültesi Dergisi, 21 (1-2) 155-190.

Dökmen, Ü. (2003). Iletişim çatışmaları ve empati. İstanbul: Sistem.

Gelbal, S. ve Duyan, V. (2010). İlköğretim öğretmenlerinin çocuk sevme durumlarına etki eden değişkenlerin incelenmesi. Hacettepe Üniversitesi Eğitim Fakültesi Dergisi, 38, 127-137.

Durmuşoğlu Salatlı, N. ve Erbay, F. (2013). Okul öncesi öğretmenlerin konuşma, dinleme ve empati becerilerinin çocuk sevme davranışı açısından incelenmesi. Ahi Evran Üniversitesi Kırşehir Eğitim Fakültesi Dergisi (KEFAD), 14 (1), 159-174.

Duyan, V. ve Gelbal, S. (2008). Barnett Çocuk Sevme Ölçeği'ni Türkçeye uyarlama çalışması. Eğitim ve Bilim, 33 (148), 40-48.

Erdem, Y. ve Duyan, V. (2011). A determination of the factors that aff ect the level of pediatric nurses' liking of children. Turk J Med Sci, 41 (2), 295-305.

Ergin, A. ve Birol, C. (2000). Eğitimde iletişim. Ankara: Anı.

Ergün, M. ve Özdaş, A. (1999). Okul gözlemi ve uygulama çalışmalarının öğretmen adayları üzerindeki etkisi. AKÜ Sosyal Bilimler Dergisi, 3, 115-119.

Ekinci, Ö. (2009). Öğretmen adaylarının empatik ve eleştirel düşünme eğilimlerinin incelenmesi. Yayımlanmamış yüksek lisans tezi, Çukurova Üniversitesi, Adana.

Eva Lu, Y., Dare, B. ve Gellman, A. (2005). An Experiential model: teaching empathy and cultural sensitivity. Journal of Teaching in Social Work, 25 (3-4), 89-103.

Hacıoğlu, M. (2007). Okul öncesi yöneticilerinin sergiledikleri iletişim becerilerinin algıları ile öğretmenlerin empati düzeyleri arasındaki ilişki. Yayımlanmamış Yüksek Lisans Tezi, Yeditepe Üniversitesi, İstanbul.

Kalaycı, Ş. (2010). SPSS uygulamalı çok değiş̧enli istatistik teknikleri. Ankara: Asil.

Karagöz, Y., Kösterelioğlu, i. (2008) iletişim becerileri değerlendirme ölçeğinin faktör analizi metodu ile geliştirilmesi, Dumlupınar Üniversitesi Sosyal Bilimler Dergisi, 21, 81-97.

Karcı, Y. (2011). iletişim meslek lisesi öğrencilerinin empatik iletişim beceri düzeylerinin incelenmesi. Selçuk iletişim, 6 (4) 155-167.

Karahan,T.F., Sardoğan, M.E., Güven, M.Ç., Özkamalı, E. ve Dicle, A.N. (2006). İnsan ilişkileri ve iletişim dersi'nin öğretmen adaylarının çatışma çözme ve empatik beceri düzeylerine etkisi. Eurasian Journal of Educational Research, 23, 127-136.

Korkut, F. (2005). Yetişkinlere yönelik iletişim becerileri eğitimi. Hacettepe Üniversitesi Eğitim Fakültesi Dergisi, 28, 143-149.

Meeks, B. S., Hendrick, S. S. ve Hendrick, C. (1998). Communication, love and relationship satisfaction. Journal of Social and Personal Relationships, 15 ( 6), 755-773.

Miller, F. ve Vallis, J. (2011). Social interaction and the role of empathy in information and knowledge management: A literature review. Journal of Education for Library and Information Science, 52 (2), 122-131.

Pala, A. (2008). Öğretmen adaylarının empati kurma düzeyleri üzerine bir araştırma, Pamukkale Üniversitesi Eğitim Fakültesi Dergisi, 1 (23), 13-23.

Şahin, F. Y. (1998). Grupla iletişim becerileri eğitiminin üniversite öğrencilerinin iletişim beceri düzeylerine etkisi. Eğitim ve Bilim, 22 (110), 12-19.

Şahin, D. ve Anlıak, ş. (2008).Okul öncesi çocuklarının öğretmenleriyle kurdukları ilişkiyi algılama biçimleri. Eğitim Bilimleri ve Uygulama, 7 (14), 215-230.

Şişman, M. (2002). Öğretim liderliği. Ankara: Pegem.

Töremen, F., Ekinci, A. ve Karakuş, M. (2006). Influence of managers' empathic skills on school success. International Journal of Educational Management, 20 (6), 490-499. 
Tutuk, A., Al, D. ve Doğan, S. (2002). Hemşirelik öğrencilerinin iletişim becerisi ve empati düzeylerinin belirlenmesi. C. Ü. Hemşirelik Yüksek Okulu Dergisi, 6 (2), 36-41.

Veenman, S. (1984). Perceived problems of beginning teachers. Review of Educational Research, 54 (2), 143-178.

Yazıcıoğlu, Y. ve Erdoğan, S. (2004). SPSS Uygulamalı bilimsel araştırma yöntemleri. Ankara: Detay.

Yüksel, A. (2004). Empati eğitim programının ilköğretim öğrencilerinin empatik becerileirne etkisi. Uludağ Üniversitesi Eğitim Fakültesi Dergisi, 17 (2), 341-354.

Zıllığlu, M. (1996). Iletişim nedir? İstanbul: Cem.

Wanzer, M. B., Butterfield, M. B. ve Gruber, K. (2004). Perceptions of health care providers'communication: relationships between patient-centered communication and satisfaction. Health Communication, 16 (3), 363-384. 